\title{
Antibacterial activity of methanol extracts of the leaves of three medicinal plants against selected bacteria isolated from wounds of lymphoedema patients
}

Dereje Nigussie $^{1,2^{*}}$ (D), Gail Davey ${ }^{2,3}$, Belete Adefris Legesse ${ }^{1}$, Abebaw Fekadu ${ }^{1,2}$ and Eyasu Makonnen ${ }^{1,4}$

\begin{abstract}
Background: Patients with lymphoedema are at high risk of getting bacterial and fungal wound infections leading to acute inflammatory episodes associated with cellulitis and erysipelas. In Ethiopia, wound infections are traditionally treated with medicinal plants.

Methods: Agar well diffusion and colorimetric microdilution methods were used to determine the antibacterial activity of methanol extracts of the three medicinal plants against Staphylococcus aureus, Streptococcus pyogenes, Escherichia coli, Klebsiella pneumoniae, Pseudomonas aeruginosa, Shewanella alage, methicillin-resistant S. aureus ATCC ${ }^{\circledR} 43300 T M$, Staphylococcus aureus ATCC25923, Escherichia coli ATCC25922, Klebsiella pneumoniae ATCC700603, and Pseudomonas aeruginosa ATCC37853.

Results: The methanol extract of L. inermis leaves showed high activity against all tested bacterial species, which was comparable to the standard drugs. Similarly, the extracts of $A$. indica showed activity against all tested species though at higher concentrations, and higher activity was recorded against Streptococcus pyogenes isolates at all concentrations. However, the extract of A. aspera showed the lowest activity against all tested species except Streptococcus pyogenes isolates. The lowest minimum inhibitory concentration (MIC) was recorded with the extract of L. inermis against $E$. coli isolate and S. aureus ATCC 25923.

Conclusion: Methanol extracts of L. inermis, A. indica, and A. aspera leaves exhibited antimicrobial activity against selected bacterial isolates involved in wound infections, of which the methanol extracts of $L$. inermis exhibited the highest activity. The results of the present study support the traditional use of plants against microbial infections, which could potentially be exploited for the treatment of wound infections associated with lymphoedema.
\end{abstract}

Keywords: Lymphoedema, Wound infection, Bacteria, Medicinal plants, Ethiopia

\footnotetext{
*Correspondence: D.Woldemichael@bsms.ac.uk; dere_nig@hotmail.com

${ }^{1}$ Centre for Innovative Drug Development and Therapeutic Trials for Africa

(CDT-Africa), College of Health Sciences, Addis Ababa University, P.O. Box 9086, Addis Ababa, Ethiopia

${ }^{2}$ Centre for Global Health Research, Brighton and Sussex Medical School, University of Sussex, Brighton BN1 9PX, UK

Full list of author information is available at the end of the article
}

C C The Author(s). 2021 Open Access This article is licensed under a Creative Commons Attribution 4.0 International License, which permits use, sharing, adaptation, distribution and reproduction in any medium or format, as long as you give appropriate credit to the original author(s) and the source, provide a link to the Creative Commons licence, and indicate if changes were made. The images or other third party material in this article are included in the article's Creative Commons. licence, unless indicated otherwise in a credit line to the material. If material is not included in the article's Creative Commons licence and your intended use is not permitted by statutory regulation or exceeds the permitted use, you will need to obtain permission directly from the copyright holder. To view a copy of this licence, visit http://creativecommons.org/licenses/by/4.0/ The Creative Commons Public Domain Dedication waiver (http://creativecommons.org/publicdomain/zero/1.0/) applies to the data made available in this article, unless otherwise stated in a credit line to the data. 


\section{Background}

Wound infections are usually associated with normal flora, bacteria from the environment or hospital-acquired infections [1]. Microorganisms infect soft tissue when the skin surface is compromised in some way. Patients with lymphoedema are at high risk of wound infection because of loss of skin integrity [2], resulting in ingress of microorganisms. Impaired clearance of microorganisms from the infected area due to impaired lymphatic system results in recurrent infections [3]. Patients with secondary lymphoedema are predisposed to cellulitis [4].

Acute inflammatory episodes associated with cellulitis and erysipelas are common complications of wounds in lymphoedema patients, and most infections are caused by group A, C, or G streptococci and Staphylococcus aureus bacteria [2]. Microorganisms known to cause chronic wound infection and cellulitis in lymphoedematous limbs include Streptococci species, Staphylococci species, Pseudomonas species, and Bacteroides species [5]. Fungal infections are also common due to the moisture produced between the skin folds, resulting in skin breakdown, which in turn leads to infection in the macerated regions. Lymphangitis is an inflammation of the lymphatic system due to bacterial infection after invasion through skin wounds or abrasions [6].

Folk medicine provides an important and unexplored resource for the discovery and development of potential new medicines against microbial infections to decrease the emergence of resistance and adverse drug reactions. Furthermore, the use of medicinal plants provides opportunities for developing countries as they may be more affordable, accessible and available [7].

Ethnobotanical studies carried out in Ethiopia reported that endemic plants have been used by traditional healers for a range of ailments, including open wound infections. However, the scientific evidence available regarding the antibacterial activity of traditionally used endemic plants against bacterial pathogens involved in wound infections of lymphoedematous limbs is limited [8].

This study, therefore, aimed to test the antibacterial activity of the leaf methanol extracts of Lawsonia inermis, Azadirachta indica, and Achyranthus aspera against selected bacteria isolated from the wounds of patients with lymphoedema and against standard ATCCs.

\section{Methods}

\section{Plant material collection}

The leaves of Lawsonia inermis (Henna) were collected from Laga Gandisa (approximately $9^{\circ} 32^{\prime} 59^{\prime \prime} \mathrm{N}$ and $41^{\circ}$ $28^{\prime} 31^{\prime \prime}$ E), $53 \mathrm{~km}$ from Dire Dawa, Ethiopia. The leaves of Azadirachta indica (Neem) were collected from Kurare Goti (approximately $10^{\circ} 7^{\prime} 15^{\prime \prime} \mathrm{N}$ and $38^{\circ} 9^{\prime} 13^{\prime \prime} \mathrm{E}$ ), $209 \mathrm{~km}$ northwest of Addis Ababa on the way to Dejen Town, Ethiopia. The leaves of Achyranthes aspera
(Telenge) were collected from the Nile Gorge (approximately $10^{\circ} 7^{\prime} 51^{\prime \prime} \mathrm{N}$, and $\left.38^{\circ} 9^{\prime} 19^{\prime \prime} \mathrm{E}\right), 210 \mathrm{~km}$ northwest of Addis Ababa on the way to Dejen, Ethiopia. No access permit was required from Ethiopian Biodiversity institute for the collection of these plants. Collection of all plant materials was carried out in consultation with a botanist from the Ethiopian Public Health Institute, local people, and traditional healers in the areas. Plant materials were authenticated by a botanist and specimens were archived at the Herbarium of Ethiopian Public Health Institute with voucher numbers of MG-012/05 for $L$. inermis, NA10 for $A$. aspera, and DG-18 for $A$. indica.

\section{Bacterial strains}

The bacterial strains for this experiment were isolated from the wounds of lymphoedema patients from East Wollega Zone. Standard reference bacteria were obtained from the National Referral Bacteriology and Mycology Laboratory, Ethiopian Public Health Institute. Clinical isolates of Staphylococcus aureus, Streptococcus pyogenes, Escherichia coli, Klebsiella pneumoniae, Pseudomonas aeruginosa, and Shewanella alage were used. Reference bacteria including MRSA Staphylococcus aureus ATCC ${ }^{\oplus} 43300^{\text {тм }}$, Staphylococcus aureus ATCC25923, Escherichia coli ATCC25922, Klebsiella pneumoniae ATCC700603 and Pseudomonas aeruginosa ATCC37853 were also used.

\section{Swab sample collection and processing}

Wounds were cleaned with sterile normal saline and wound swabs and discharge were obtained from all study participants aseptically using a sterile moistened cotton swab. Swabs were then immersed in a container of Amies transport medium with charcoal (Bio mark Laboratories, Pune, India). All samples were transported on ice to the Ethiopian Public Health Institute, National Referral Bacteriology and Mycology Laboratory (Ethiopian National Accreditation Office accredited and ranked as Five Star by the American Society for Microbiology) where all laboratory tests were conducted. Swabs were used to inoculate MacConkey agar (Becton Dickinson and Company, Cockeysville, MD, USA), blood agar and mannitol salt agar (both from HiMedia Laboratories, Mumbai, India) and incubated aerobically at $37^{\circ} \mathrm{C}$, and $5 \%$ CO2 for $24 \mathrm{~h}$. After $24 \mathrm{~h}$, plates without growth were incubated further for up to $48 \mathrm{~h}$.

Growth of micro-organisms was identified by examining colony morphology followed by biochemical identification using the automated VITEK $^{\oplus} 2$ COMPACT Microbial $^{-1}$ Detection System (bioMerieux, Marcy l'Etoile, France).

\section{Extraction and preparation of plant materials}

The extraction of each plant material was done following methods previously used with slight modifications [9]. 
Each plant material powder was successively extracted with three organic solvents in order of increasing polarity (petroleum ether $\rightarrow$ ethyl acetate $\rightarrow$ methanol $\rightarrow$ aqueous). Three hundred grams of each powder was soaked in $1.5 \mathrm{l}$ of petroleum ether separately and kept on a VWR DS 500 orbital shaker for $72 \mathrm{~h}$. The extracts were filtered using WhatmanNo1 filter paper. The residue was further extracted twice with fresh petroleum ether. Then, all the filtrates were mixed. The resulting residues were air-dried and further extracted with ethyl acetate, methanol, and sterile water using the procedure employed for petroleum ether extraction. Organic solvents were then removed from the extracts using rotavapor and the extracts were kept for several days in a water bath $\left(40^{\circ} \mathrm{C}\right)$. After complete drying, the yield of each extract was measured separately, and the extracts were stored at $4^{\circ} \mathrm{C}$ until used for further study. The dried extracts of $A$. aspera, L. inermis and A. indica were dissolved in $10 \%$ DMSO and kept at $4^{\circ} \mathrm{c}$ until used for the experiments.

\section{Preliminary phytochemical screening of the extracts} Phytochemical analysis of the methanol extract of $A$. aspera, L. inermis and A. indica leaves was performed using standard procedures to determine the active constituents present in the extracts. Tests for alkaloids, saponins, phenols, tannins, anthraquinones, terpenoids, flavonoids and steroids were performed following the methods developed before [10].

\section{Test for alkaloids}

Extracts from plants were dissolved in $\mathrm{HCl}$ and filtered for the following tests.

a. Mayer's Test: Filtrates were treated with Mayer's reagent (Potassium Mercuric Iodide). Yellow precipitation indicates the presence of alkaloids in the extracts.

b. Dragendroff's Test: Filtrates were treated with Dragendroff's reagent (solution of Potassium Bismuth Iodide). Red precipitation indicates the presence of alkaloids in the extracts.

\section{Test for saponins (foam test)}

Extract was shaken with $2 \mathrm{ml}$ of water. If foam produced persists for $10 \mathrm{~min}$, it indicates the presence of saponins.

\section{Phenol test}

$0.5 \mathrm{G}$ crude extracts was treated with a few drops of $2 \%$ $\mathrm{FeCl}_{3}$ bluish green or black colouration indicated presence of phenolic compound

\section{Test for tannins (ferric chloride test)}

Each plant extract was stirred with $1 \mathrm{ml}$ of distilled water, after filtered, ferric chloride reagent added to the filtrate. A blue-black, green, or blue-green precipitate indicates the presence of tannins.

\section{Test for anthraquinones}

Chloroform was added to the extracts and shaken for 5 $\mathrm{min}$. The extract was filtered and shaken with an equal volume of $100 \%$ ammonia solution. A pink, violet or red colour in the ammoniacal layer (lower layer) indicated the presence of free anthraquinones.

\section{Test for terpenoids}

Each extract was dissolved in chloroform, then $3 \mathrm{ml}$ of concentrated sulfuric acid was added carefully and examined: reddish brown coloration indicates the presence of terpenoid.

\section{Test for steroids}

Chloroform $10 \mathrm{ml}$ was added to $2 \mathrm{ml}$ of all three plant extracts. To these extracts $1 \mathrm{ml}$ of acetic anhydride was added and then $2 \mathrm{ml}$ of concentrated sulphuric acid was added along the sides of the test tube. Colour formation at the junction is noted. The appearance of blue green colour indicates the presence of steroids.

\section{Test for flavonoids (alkaline reagent test)}

Extracts were treated with drops of sodium hydroxide solution. Formation of intense yellow colour, which becomes colourless on addition of dilute acid, shows presence of flavonoids.

\section{Bacterial culture and inoculum preparation}

Fresh cultures of bacteria were prepared from frozen stock, streaked on Mueller Hinton agar (MHA) plates and incubated for $24 \mathrm{~h}$ at $37^{\circ} \mathrm{C}$ in an incubator. After18-24 h of incubation, a single colony of microorganisms was picked and inoculated into $3 \mathrm{~mL}$ sterile saline solution. The saline tube was then vortexed to create a uniform solution, and turbidity was adjusted to 0.5 McFarland standard $\left(10^{8} \mathrm{CFU} / \mathrm{mL}\right)$.

\section{Antibacterial activity assays \\ The agar well diffusion assay}

The Kirby-Bauer technique was used to determine the antibacterial activity of the extracts [11]. A total of 11 bacteria strains were used for this test. Mueller Hinton agar ( $\mathrm{pH} 7.2$ \& $4 \mathrm{~mm}$ depth) plates were inoculated with test organisms (prepared in a sterile saline tube) by streaking the loop in a back-and-forth motion to ensure an even distribution of inoculum. MHA with 5\% sheep blood was used for Streptococcus pyogenes. A circular 6 $\mathrm{mm}$ diameter well was punched aseptically with a sterile 
cork borer. Then, a volume of $100 \mu \mathrm{L}$ methanol extracts of $A$. aspera, L. inermis and A. indica leaves (at concentrations of $100 \mathrm{mg} / \mathrm{mL}, 200 \mathrm{mg} / \mathrm{mL}$, and $400 \mathrm{mg} / \mathrm{mL}$ ) were dispensed into the wells. Similarly, 5\% Di-methylsulfoxide (DMSO) was dispensed into the control well, and reference antibiotic discs were placed on the surface of the plate and incubated for $24 \mathrm{~h}$ at $37^{\circ} \mathrm{C}$. For Streptococcus pyogenes, a carbon dioxide incubator was used for incubation. Each experiment was done three times.

\section{Microdilution method}

The minimum inhibitory concentration (MIC) and minimum bactericidal concentration $(\mathrm{MBC})$ of the extracts were determined using the p-iodonitrotetrazolium chloride (INT) colorimetric assay method [12]. The test was done according to the recommendations of the Clinical Laboratory Standard Institute [13]. Bacteria were subcultured on Mueller Hinton agar ( $\mathrm{pH}$ 7.2) and incubated at $37^{\circ} \mathrm{C}$ for $24 \mathrm{~h}$. Bacterial colonies were inoculated into a sterile saline solution and used before $30 \mathrm{~min}$. The bacterial suspension was evenly mixed and diluted to meet the turbidity of $0.5 \mathrm{McF}$ arland standard $\left(1 \times 10^{8} \mathrm{CFU} /\right.$ $\mathrm{mL})$. Further dilution was performed to obtain the final concentration of inoculum $\left(5 \times 10^{5} \mathrm{CFU} / \mathrm{mL}\right)$ in each well. A stock solution of plant extracts was prepared in DMSO. Serial dilutions of the working solution were prepared by diluting the extract solution in sterile Mueller Hinton Broth. The final concentration of DMSO in the solution was less than $2.8 \%$ in the solution. The test was performed in a sterile 96-well plate. Methanol extracts of A. aspera, L. inermis, and A. indica leaves were tested in triplicate in one plate for each bacterium. Mueller Hinton Broth $(100 \mu \mathrm{L})$ was dispensed to all wells. A working solution of extracts $(100 \mu \mathrm{L})$ and solvent controls ( $\mathrm{MH}$ broth and 2.8\% DMSO) were dispensed into their respective wells. Serial dilutions were performed from columns one to nine, and $50 \mu \mathrm{L}$ of excess medium was discarded from column nine. The last column served as a blank containing only broth. Columns 10 and 11 served as negative controls, which only contained medium and bacterial suspension, and media DMSO and bacteria, respectively. $50 \mu \mathrm{L}$ of test bacteria were added to each well except for the last row, which served as a blank. The concentration of plant extracts ranged from $0.78 \mathrm{mg} / \mathrm{mL}$ to $200 \mathrm{mg} / \mathrm{mL}$. The plates were sealed and incubated for $24 \mathrm{~h}$ at $37^{\circ} \mathrm{C}$. After $24 \mathrm{~h}$ incubation, $40 \mu \mathrm{L}(0.2 \mathrm{mg} / \mathrm{mL})$ p-iodonitrotetrazolium chloride (INT) was added to all wells and incubated again at $37^{\circ} \mathrm{C}$ for $30 \mathrm{~min}$. The MIC of the samples was detected after $30 \mathrm{~min}$ of incubation. Viable bacteria reduced the yellow dye to pink. MIC was defined as the sample concentration that prevented the colour change of the medium and exhibited complete inhibition of microbial growth. The $\mathrm{MBC}$ was determined by adding $50 \mu \mathrm{L}$ aliquots from the wells that did not show growth after incubation for the MIC test to $150 \mu \mathrm{L}$ broth in the well plate, and incubated for $48 \mathrm{~h}$ at $37^{\circ} \mathrm{C}$. Then, MBC was observed as the lowest concentration of extracts which did not produce a colour change after the addition of INT as mentioned above.

\section{Statistical analysis}

Statistical Package for Social Science (SPSS) version 20 was used for descriptive analyses, such as frequencies and means. Statistical differences in the mean zones of inhibition for individual bacteria and differences in the susceptibility of the test microorganisms were analysed using ANOVA followed by Tukey's post hoc at a significance level of $P<0.05$. MIC was analysed using descriptive statistics.

\section{Results}

\section{Plant extract yield and properties}

The percent yields of the methanol extracts of $A$. aspera, $L$. inermis and $A$. indica and their properties are given in Table 1. Maximum yield was obtained from $L$. inermis (15.9\%), followed by $A$. aspera $(14.7 \%)$ and $A$. indica (7.9\%).

\section{Preliminary phytochemical screening of the extracts}

The methanol extracts of $L$. inermis, A. aspera and $A$. indica leaves tested positive for alkaloids, terpenoids, phenolic compounds, tannins and steroids tests. Furthermore, $L$. inermis contained anthraquinones, whereas $A$. indica contained saponins and flavonoids. However, $L$. inermis did not contain flavonoids or saponins, and flavonoids were absent from $A$. aspera. A. indica was negative for the anthraquinones test (Table 2).

\section{Antibacterial activity}

The antibacterial activities of the methanol extracts of $L$. inermis, $A$. aspera and A. indica leaves were tested against microorganisms isolated from the wounds of patients with lymphoedema and standard ATCCs. In vitro antibacterial activity was tested in the presence or absence of a zone of inhibition in diameter, the minimum inhibitory concentration (MIC) and minimum bactericidal concentration $(\mathrm{MBC})$ in comparison with the reference antibacterial drugs.

Generally, it was observed that bacterial growth inhibition increased as the concentration of the extracts increased. Pairwise comparison of ANOVA was used to test the variability in susceptibility of the microorganisms toward the extracts $(p<0.05)$. No significant difference was observed in terms of susceptibility between $K$. pneumoniae isolates and ATCC $(p=0.91), S$. algae isolates and $P$. aeruginosa ATCC $(p=0.74), E$. coli isolates and $K$. pneumoniae ATCC $(p=0.89), S$. aureus isolates 
Table 1 Extraction yield of the plants in methanol

\begin{tabular}{llll}
\hline Plant name with parts & Appearance & Consistency & Yield (\% w/w) \\
\hline Lawsonia inermis (leaves) & Brown & Semisolid & 15.9 \\
Achyranthes aspera (leaves) & Dark green & Semisolid & 14.7 \\
Azadirachta indica (leaves) & Grey & Powder & 7.9 \\
\hline
\end{tabular}

and MRSA ATCC $(p=1.0)$, or $S$. aureus isolates and $E$. coli ATCC $(p=1.0)$. There was a significant difference in the zone of inhibition between $L$. inermis and the other two plant extracts, $A$. aspera and $A$. indica. However, no significant growth inhibition difference was detected between $A$. indica and A. aspera $(p=0.55)$.

The Streptococcus pyogenes isolate showed the highest susceptibility to all the extracts at all concentrations compared with the standard drugs. $K$. pneumoniae ATCC700603, K. pneumoniae isolates and P. aeruginosa isolates showed low levels of susceptibility against all extracts (Figs. 1 and 2).

All three concentrations $(100,200$, and $400 \mathrm{mg} / \mathrm{mL})$ of L. inermis showed significant activity against all tested bacteria species, which was comparable to the standard drugs. The highest zone of inhibition was recorded by $L$. inermis against all tested species except $K$. pneumonia ATCC700603, P. aeruginosa isolates and K. pneumonia isolates. $L$. insermis showed exceptional activity against E. coli isolates, S. aureus ATCC 25923, and MRSA ATCC $^{\circ} 43300^{\text {max }}$, which was comparable to the conventional drug cefoxitin (Table 3).

$A$. indica extract was shown to have activity against all tested species at high concentrations, and high activity was recorded against Streptococcus pyogenes isolates at all concentrations $(100,200$, and $400 \mathrm{mg} / \mathrm{mL})$. However, $100 \mathrm{mg} / \mathrm{mL}$ and $200 \mathrm{mg} / \mathrm{mL}$ concentrations showed low activity against all tested strains. A. aspera showed the lowest activity against all tested species, except against Streptococcus pyogenes isolate $(10.5 \pm 0.9$ to $13.3 \pm 0.6$ $\mathrm{mm}$ ZI) compared with the reference drug cefoxitin (15-24 mm) (Table 3). There were significant differences

Table 2 Preliminary phytochemical screening for secondary metabolites

\begin{tabular}{lllll}
\hline S/N & Secondary metabolites & L. inermis & A. aspera & A. indica \\
\hline 1 & Alkaloids & + & + & + \\
2 & Terpenoids & + & + & + \\
3 & Saponins & + & - & + \\
4 & Flavonoids & - & - & + \\
5 & Phenols & + & + & + \\
6 & Tannins & + & + & + \\
7 & Anthraquinones & + & - & - \\
8 & Steroids & + & + & + \\
\hline+
\end{tabular}

$+=$ present,$-=$ absent in the mean zone of inhibition between the different concentrations of $L$. inermis, $A$. aspera and $A$. indica $(p<0.05)$.

Among the strains, S. aureus, E. coli, P. aeruginosa, and $K$. pneumonia isolates were less susceptible to $L$. inermis than the standard ATCCs. Similarly, multi-drug resistant $S$. aureus (MRSA) was less susceptible to all tested extracts compared to $S$. aureus isolate and standard ATCC. All the references used in the test showed the highest activity against their respective tested species. The mean inhibition zones of triplicate experiments for the three different concentrations of extracts (100, 200 and $400 \mathrm{mg} / \mathrm{mL}$ ) are summarized in Table 3.

The methanol extracts of the three plant leaf extracts showed different levels of MIC against all tested bacteria. There was no inhibition of growth of bacteria in the negative controls (medium and bacterial suspension, and media DMSO and bacteria). The colorimetric broth microdilution assay showed that the methanol extract of L. inermis inhibited the growth of eleven tested microorganisms within the concentration ranges of $1.5 \pm 1.4$ to $12.5 \pm 0.0 \mathrm{mg} / \mathrm{mL}$. Whereas, the minimum bactericidal concentration $(\mathrm{MBC})$ ranged from $12.00 \pm 0.0$ to $83.3 \pm$ 28.9 among the strains.

The MICs were recorded for $L$. inermis against $E$. coli isolate $(1.5 \pm 1.4 \mathrm{mg} / \mathrm{mL})$ and $S$. aureus ATCC 25923 $(3.1 \pm 0.0 \mathrm{mg} / \mathrm{mL})$, and the lowest $\mathrm{MBC}$ against $E$. coli isolate $(12.00 \pm 0.0 \mathrm{mg} / \mathrm{mL})$. The highest MIC value of $L$. inermis was against $K$. pneumoniae ATCC700603 and E. coli ATCC 25922 which was $12.0 \pm 0.0 \mathrm{mg} / \mathrm{mL}$ for both (Table 4).

Similarly, the MICs of $A$. indica ranged from $25.0 \pm$ $0.0 \mathrm{mg} / \mathrm{mL}$ to $100.0 \pm 0.0 \mathrm{mg} / \mathrm{mL}$ among the tested strains, and $\mathrm{MBC}$ ranges from $36.7 \pm 23$ to $200.0 \pm 0.0$ $\mathrm{mg} / \mathrm{mL}$. The lowest MIC of $A$. indica was observed against $S$. aureus and $K$. pneumonia isolates, and the highest values were against $P$. aeruginosa and S. algae isolates (Table 4). The lowest MBC of $A$. indica was observed against $S$. pyogenes isolate $(36.7 \pm 23 \mathrm{mg} / \mathrm{mL})$ (Table 3.10). Similarly, the MICs of methanol extracts of A. aspera ranged from $50.0 \pm 0.0-200.0 \pm 0.0 \mathrm{mg} / \mathrm{mL}$. The minimum bactericidal concentration for the three plant extracts was $\geq 200.0 \mathrm{mg} / \mathrm{mL}$, except for $S$. aureus isolate and S. pyogenes isolate which was $100.0 \pm 0.0 \mathrm{mg} /$ $\mathrm{mL}$ for both (Table 4). 


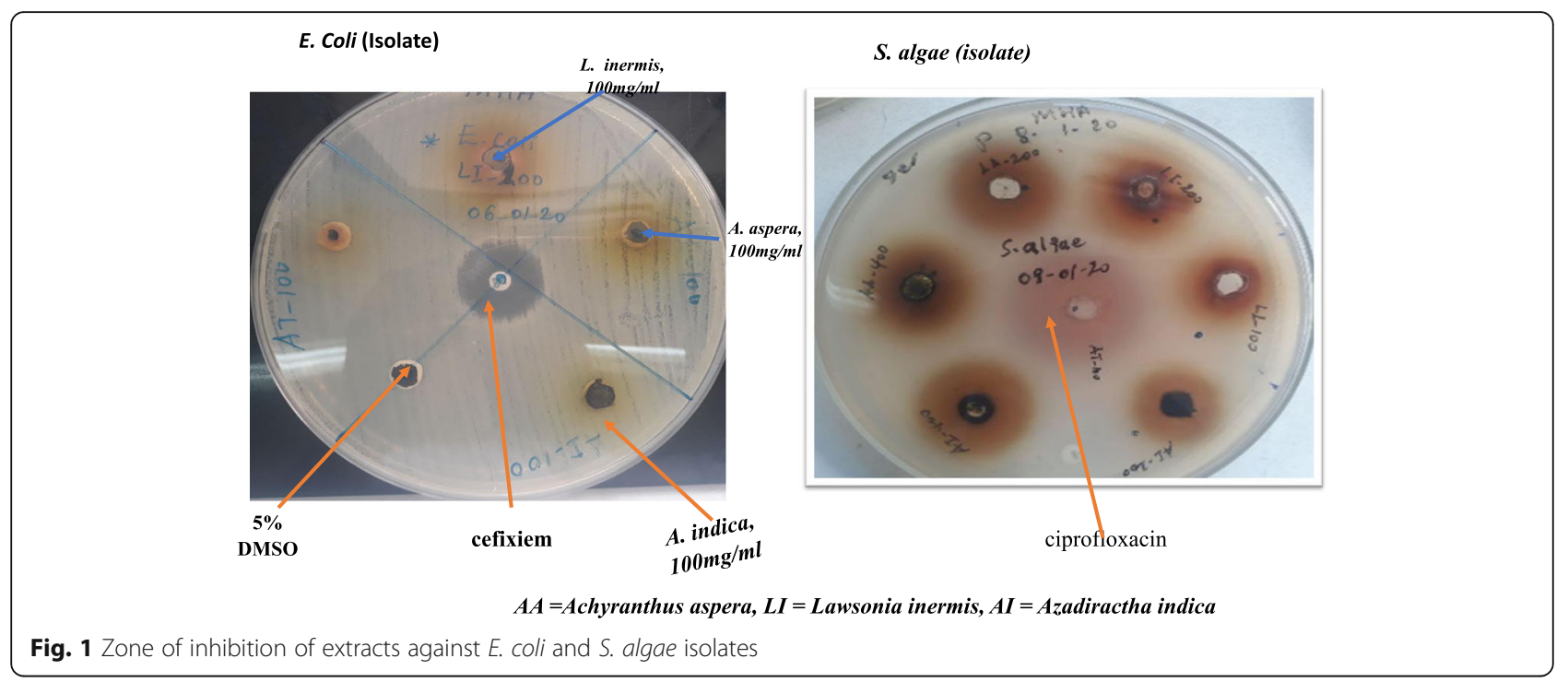

\section{Discussion}

Natural products contain a range of lead compounds which may enable the development of novel antimicrobial agents as conventional antimicrobial drugs become ineffective due to emergence of resistance. The secondary metabolites present in a medicinal plant may have different modes of antimicrobial action which help combat the emergence of resistance [14].

Assessing the antibacterial activity of herbal medicines for their potential use in treatment of skin and wound infections has great importance. The antibacterial activity observed in the present study suggests that among the plant extracts tested are some that could be used for the management of wound infections in patients with lymphoedema.
Qualitative tests for secondary metabolites in methanol extracts of $L$. inermis leaves revealed the presence of alkaloids, terpenoids, saponins, phenols, tannins, anthraquinones and steroids which may be responsible for the antibacterial activity demonstrated. Which is in agreement The metabolites documented are in line with previous findings [15] with the exception of the absence of flavonoids. L. inermis is a source of unique and valuable natural compounds that have been considered for a wide range of disease conditions as well as cosmetics [16].

The methanol extract of $L$. inermis leaves had significant activity against all tested bacteria. Among the tested strains, S. aureus ATCC 25923, MRSA ATCC 43300 TM, E. coli ATCC 25922, E. coli, and Streptococcus pyogenes isolates were the most susceptible, with a zone of inhibition comparable to cefoxitin and penicillin at all tested

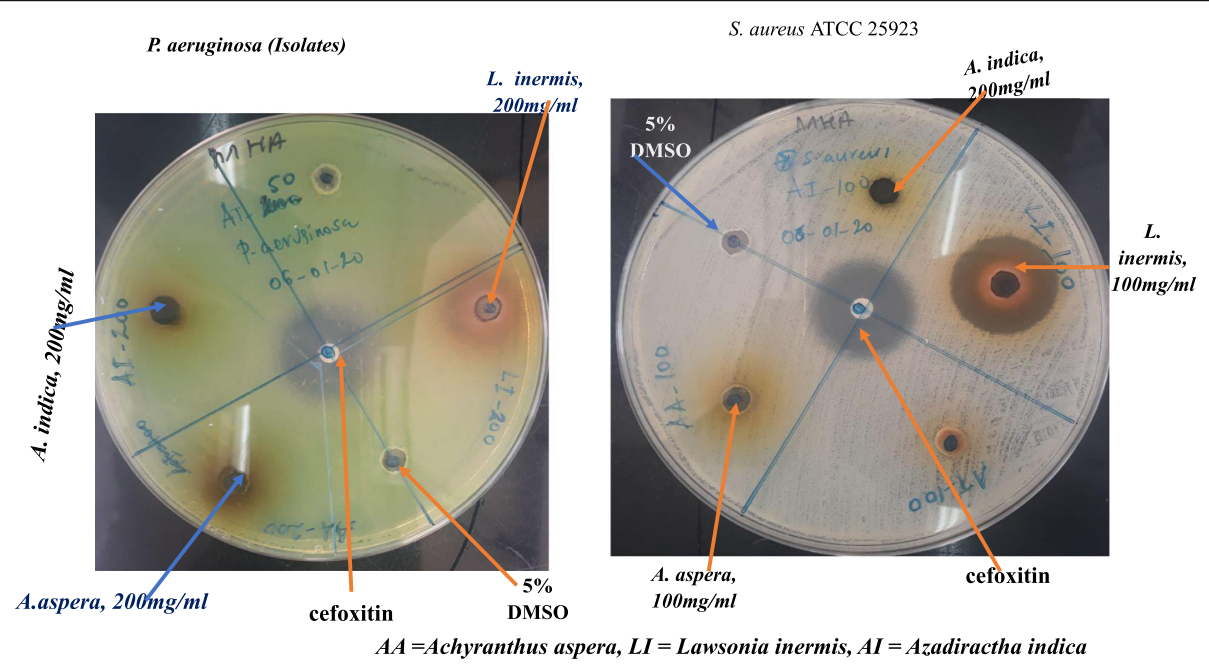

Fig. 2 Zone of inhibition of extracts against $P$. aeruginosa and S. aureus isolates 
Table 3 Mean inhibition zone of bacterial growth $(\mathrm{mm})$ for the leaves of methanol extracts of $L$. inermis, A. aspera and A. indica leaves

\begin{tabular}{|c|c|c|c|c|c|c|c|c|c|c|c|c|}
\hline \multirow[t]{3}{*}{ Plants } & \multirow{3}{*}{$\begin{array}{l}\text { Conc. } \\
\text { (mg/ } \\
\mathrm{mL})\end{array}$} & \multicolumn{11}{|c|}{ Zone of inhibition $(\mathrm{mm})($ Mean \pm SD) } \\
\hline & & \multicolumn{2}{|l|}{ S. aureus } & \multicolumn{2}{|l|}{ E. coli } & \multicolumn{2}{|c|}{ P. aeruginosa } & \multicolumn{2}{|c|}{ K. pneumoniae } & \multirow{2}{*}{$\begin{array}{l}\text { MRSA } \\
\text { ATCC }\end{array}$} & \multirow{2}{*}{$\begin{array}{l}\text { S. pyogenes } \\
\text { Isolate }\end{array}$} & \multirow{2}{*}{$\begin{array}{l}\text { Shewanella algae } \\
\text { Isolate }\end{array}$} \\
\hline & & ATCC & Isolate & ATCC & Isolate & ATCC & Isolate & ATCC & Isolate & & & \\
\hline \multirow[t]{3}{*}{$\overline{\mathrm{LI}}$} & 100 & $33.0 \pm 1.0$ & $15.5 \pm 0.5$ & $15.1 \pm 0.7$ & $8.1 \pm 0.4$ & $20.5 \pm 0.5$ & $12.5 \pm 0.5$ & $8.2 \pm 0.3$ & $7.6 \pm 0.5$ & $15.1 \pm 0.7$ & $21.0 \pm 1.0$ & $20.5 \pm 0.5$ \\
\hline & 200 & $31.0 \pm 1.0$ & $17.5 \pm 0.5$ & 19.30 .6 & $10.3 \pm 0.8$ & $21.2 \pm 0.7$ & $13.8 \pm 0.8$ & $9.6 \pm 0.5$ & $8.8 \pm 0.7$ & $19.3 \pm 0.6$ & $24.5 \pm 0.5$ & $21.2 \pm 1.1$ \\
\hline & 400 & $33.0 \pm 1.0$ & $21.3 \pm 1.5$ & $21.2 \pm 0.3$ & $12.1 \pm 0.6$ & $21.5 \pm 0.9$ & $15.6 \pm 0.5$ & $10.5 \pm 0.9$ & $10.8 \pm 0.8$ & $21.2 \pm 0.3$ & $25.9 \pm 0.9$ & $21.9 \pm 1.0$ \\
\hline \multirow[t]{3}{*}{$\mathrm{AA}$} & 100 & $7.1 \pm 0.6$ & $6.3 \pm 0.6$ & $6.4 \pm 0.5$ & $6.8 \pm 0.8$ & $6.4 \pm 0.4$ & $6.2 \pm 0.3$ & $6.4 \pm 0.4$ & $6.0 \pm 0.0$ & $6.6 \pm 0.6$ & $10.5 \pm 0.9$ & $6.5 \pm 0.5$ \\
\hline & 200 & $9.1 \pm 0.4$ & $6.5 \pm 0.5$ & $6.6 \pm 0.6$ & $7.4 \pm 0.5$ & $6.5 \pm 0.5$ & $6.6 \pm 0.5$ & $6.8 \pm 0.7$ & $6.5 \pm 0.5$ & $7.5 \pm 0.6$ & $12.9 \pm 1.0$ & $6.6 \pm 0.7$ \\
\hline & 400 & $6.3 \pm 0.4$ & $7.0 \pm 1.0$ & $7.5 \pm 0.6$ & $7.6 \pm 0.5$ & $6.7 \pm 0.6$ & $7.0 \pm 1.0$ & $7.2 \pm 1.0$ & $6.5 \pm 0.5$ & $7.4 \pm 0.4$ & $13.3 \pm 0.6$ & $6.8 \pm 0.8$ \\
\hline \multirow[t]{3}{*}{$\mathrm{Al}$} & 100 & $6.4 \pm 0.4$ & $6.2 \pm 0.3$ & $6.3 \pm 0.4$ & $6.6 \pm 0.5$ & $6.4 \pm 0.4$ & $6.4 \pm 0.4$ & $6.4 \pm 0.5$ & $6.1 \pm 0.2$ & $6.3 \pm 0.4$ & $16.7 \pm 0.6$ & $6.3 \pm 0.6$ \\
\hline & 200 & $6.7 \pm 0.3$ & $6.7 \pm 0.6$ & $6.5 \pm 0.5$ & $7.4 \pm 0.4$ & $6.8 \pm 0.7$ & $6.8 \pm 0.7$ & $6.6 \pm 0.6$ & $6.1 \pm 0.2$ & $6.5 \pm 0.5$ & $18.3 \pm 0.6$ & $7.4 \pm 0.5$ \\
\hline & 400 & $7.4 \pm 0.4$ & $8.2 \pm 0.7$ & $7.5 \pm 0.7$ & $6.3 \pm 0.3$ & $7.8 \pm 0.2$ & $7.5 \pm 0.5$ & $8.5 \pm 0.5$ & $7.4 \pm 0.5$ & $6.4 \pm 0.5$ & $21.0 \pm 1.0$ & $9.5 \pm 0.5$ \\
\hline \multicolumn{2}{|c|}{$5 \mu \mathrm{g}$ cefoxitin } & $27.0 \pm 0.0$ & $27.0 \pm 0.0$ & $24.0 \pm 0.0$ & $24.0 \pm 0.0$ & $29.0 \pm 0.0$ & $29.0 \pm 0.0$ & $24.0 \pm 0.0$ & $24.0 \pm 0.0$ & $15.0 \pm 0.0$ & - & - \\
\hline \multicolumn{2}{|c|}{$\begin{array}{l}5 \mu \mathrm{g} \\
\text { ciprofloxacin }\end{array}$} & - & - & - & - & - & - & - & - & - & - & $24.0 \pm 0.0$ \\
\hline \multicolumn{2}{|c|}{$10 \mu g$ penicillin } & - & - & - & - & - & - & - & - & - & $24.0 \pm 0.0$ & - \\
\hline \multicolumn{2}{|c|}{$5 \%$ DMSO } & $\mathrm{NI}$ & $\mathrm{NI}$ & $\mathrm{NI}$ & $\mathrm{NI}$ & $\mathrm{Nl}$ & $\mathrm{NI}$ & $\mathrm{NI}$ & $\mathrm{NI}$ & $\mathrm{Nl}$ & $\mathrm{NI}$ & $\mathrm{NI}$ \\
\hline
\end{tabular}

Values are triplicate and represented as mean \pm SD. Al Azadirachta indica, LI Lawsoni ainermis, AA Achranthes aspera, NI No inhibition

concentrations. This finding supports the work of Manivannan et al. [17], Kannahi et al. [18], and Badoni et al. [19]. ß-asarones, the active constituents found in the leaves, roots, and rhizomes of the L. inermis, were responsible for all antimicrobial activities [20].

The quinones present in L. inermis (henna) were found to possess high activity against all microorganisms [17]. In the methanol extract of $L$. Inermis leaves, alkaloids, anthraquinones, and saponins have been reported to have antibacterial activity, and the high activity against most microorganisms may be due to a single or combined effect of these secondary metabolites [21].

Azadirachta indica is one of the most useful medicinal plant, whose plant parts have been used as traditional medicine with proven antiseptic, antiviral, antipyretic, anti-inflammatory, antiulcer and antifungal properties [22]. Our study showed that the methanol extract of $A$. indica leaves contained alkaloids, terpenoids, saponins, flavonoids, phenols, tannins, and steroids, which is in agreement with previous reports [22]. Phytochemical constituents such as flavonoids and saponins could be

Table 4 The mean values of MIC and MBC for the methanol extracts of Lawsonia inermis, Achyranthes aspera and Azadirachta indica leaves

\begin{tabular}{|c|c|c|c|c|c|c|c|}
\hline \multirow{2}{*}{$\begin{array}{l}\mathrm{S} / \\
\mathrm{N}\end{array}$} & \multirow[t]{2}{*}{ Bacteria } & \multicolumn{3}{|c|}{ MIC (mg/mL) } & \multicolumn{3}{|c|}{$\mathrm{MBC}(\mathrm{mg} / \mathrm{mL})$} \\
\hline & & LI & Al & $A A$ & LI & Al & $A A$ \\
\hline 1 & S. aureus ATCC 25923 & $3.1 \pm 0.0$ & $33.3 \pm 14.4$ & $50.0 \pm 0.0$ & $25.0 \pm 0.0$ & $200.0 \pm 0.0$ & $200.0 \pm 0.0$ \\
\hline 2 & MRSA S. aureus ATCC ${ }^{\oplus} 43300^{\mathrm{TM}}$ & $4.2 \pm 2.0$ & $33.3 \pm 14.4$ & $42.0 \pm 14.4$ & $50.0 \pm 0.0$ & $200.0 \pm 0.0$ & $>200.00$ \\
\hline 3 & E. coli ATCC 25922 & $12.5 \pm 0.0$ & $83.3 \pm 29.0$ & $66.7 \pm 28.9$ & $25.0 \pm 0.0$ & $200.0 \pm 0.0$ & $200.0 \pm 0.0$ \\
\hline 4 & P. aeruginosa ATCC27853 & $4.2 \pm 1.8$ & $50.0 \pm 0.0$ & $200.0 \pm 0.0$ & $18.8 \pm 10.8$ & $200.0 \pm 0.0$ & $200.0 \pm 0.0$ \\
\hline 5 & K. pneumoniae ATCC700603 & $12.5 \pm 0.0$ & $41.7 \pm 14.4$ & $50.0 \pm 0.0$ & $83.3 \pm 28.9$ & $100.0 \pm 0.0$ & $>200.00$ \\
\hline 6 & E. coli isolate & $1.5 \pm 1.4$ & $83.3 \pm 28.9$ & $100.0 \pm 0.0$ & $12.00 \pm 0.0$ & $100.00 \pm 0.0$ & $200.0 \pm 0.0$ \\
\hline 7 & K. pneumoniae isolate & $7.3 \pm 4.8$ & $25.0 \pm 0.0$ & $50.0 \pm 0.0$ & $50.0 \pm 0.0$ & $100.0 \pm 0.0$ & $>200$ \\
\hline 8 & P. aeruginosa isolate & $12.5 \pm 0.0$ & $100.0 \pm 0.0$ & $166.7 \pm 57.7$ & $66.7 \pm 28.9$ & $200.0 \pm 0.0$ & $>200$ \\
\hline 9 & Shewanella algae isolate & $6.25 \pm 0.0$ & $100.0 \pm 0.0$ & $200.0 \pm 0.0$ & $83.3 \pm 28.9$ & $100.0 \pm 0.0$ & $>200$ \\
\hline 10 & S. aureus isolate & $6.25 \pm 0.0$ & $25.0 \pm 0.0$ & $50.0 \pm 0.0$ & $25.0 \pm 0.0$ & $50.0 \pm 0.0$ & $100.0 \pm 0.0$ \\
\hline 11 & S. pyogenes isolate & $6.25 \pm 0.0$ & $33.3 \pm 14.4$ & $83.3 \pm 28.9$ & $41.7 \pm 14.4$ & $36.7 \pm 23$ & $100.0 \pm 0.0$ \\
\hline
\end{tabular}

Values are triplicate and represented as mean \pm SD. MIC Minimum inhibitory concentration, MBC Minimum bactericidal concentration, $L I$ Lawsonia inermis, $A$ I Azadirachta indica, AA Achyranthes aspera 
responsible for the anti-inflammatory, antimicrobial, antioxidant, and antiviral activity of the plant [22].

$A$. indica extract was found to have moderate activity against all tested strains except $E$. coli isolate $(6.3 \pm 0.3$ $\mathrm{mm} \mathrm{ZI})$ and MRSA $(6.4 \pm 0.5 \mathrm{~mm} \mathrm{ZI})$ at $400 \mathrm{mg} / \mathrm{mL}$. In comparison with the reference drugs, the highest activity of $A$. indica extract was recorded against Streptococcus pyogenes isolate $(21.0 \pm 1.0 \mathrm{~mm} \mathrm{ZI)}$, followed by Shewanella algae $(9.0 \pm 0.5 \mathrm{~mm} \mathrm{ZI})$ at $400 \mathrm{mg} / \mathrm{mL}$. Clinical isolates of E. coli, P. aeruginosa, and $K$. pneumonia strains were found to be less susceptible than the standard ATCCs at the tested concentrations. A. indica extract at concentrations of $100 \mathrm{mg} / \mathrm{mL}$ and $200 \mathrm{mg}$ showed low activity against the tested strains, except for Streptococcus pyogenes and S. algae (Fig. 2).

$S$. aureus isolates were more susceptible than the standard ATCC. Previous studies showed that the methanol extract of $A$. indica (neem) had high activity against standard and clinical isolated strains of $P$. aeruginosa [23]. Another study indicated that ethanol extracts of $A$. indica (neem) leaf exhibited antibacterial activity against E. coli, K. pneumoniae, Proteus mirabilis, S. aureus, P. aeruginosa, and Enterococcus faecalis at 100, 50, and $25 \mathrm{mg} / \mathrm{mL}$ [24].

Achyranthes aspera locally known as "Telegne" is traditionally used in Ethiopia for treatment of a range of wound infections [25]. It was reported to have antibacterial, anti-inflammatory, analgesic, and antipyretic activities [26]. Previous studies on methanol extracts of A. aspera (leaves) showed secondary metabolites such as alkaloids, terpenoids, phenols and tannins which might be responsible for the pharmacological activities of the plant extract [27].

In this study, the methanol extract of $A$. aspera leaves showed high antibacterial activity against Streptococcus pyogenes at $400 \mathrm{mg} / \mathrm{mL}$, and low activity against the other strains at tested concentrations. Next to Streptococcus pyogenes, $S$. aureus ATCC was found to be more susceptible than the clinical isolate. Except for the Streptococcus pyogenes strain, this finding agrees with the report of Taye et al [28], in which gram-positive bacteria were more susceptible than gram-negatives to the plant extracts, perhaps due to the nature of their cell walls. Gram-negatives have phospholipid membranes carrying structural lipopolysaccharide components that makes their cell wall impermeable to some antimicrobial substances [29].

The minimum inhibitory concentration (MIC) is defined as the lowest concentration of antimicrobial agent that inhibited the visible growth of microorganisms after overnight incubation. The MBC is complementary to the MIC. It demonstrates the lowest level of antimicrobial agent that results in microbial death after sub culturing the organism in an antibiotic-free media [30]. The
MIC is used to evaluate the antimicrobial effectiveness of new compounds or extracts by measuring the effect of decreasing the antimicrobial concentration. Antimicrobials with lower MIC are considered to be more effective.

The MIC values obtained from the present study indicated that the methanol extract of $L$. inermis leaves was more potent against E. coli isolate and S. aureus ATCC 25923, which agrees with the initial antimicrobial screening test results (agar well diffusion test). Strong antibacterial activity was also observed against $S$. aureus ATCC 25923, MRSA ATCC ${ }^{\circ} 43300$ TM, and P. aeruginosa ATCC27853 at low concentrations of L. inermis extract. The results of our study agree with those of previous report from Jordan [31]. The differences in bacterial susceptibility could be due to variations in intrinsic tolerance of microorganisms, or the physico-chemical properties of phytochemicals present in the crude extracts of the plant materials [31].

The MBC/MIC ratio was determined for $L$. inermis extract to determine whether the extract was bactericidal or bacteriostatic at the tested concentrations. The $\mathrm{MBC} /$ MIC ratio greater than 4 is usually considered to be a bacteriostatic effect; whereas values less than 4 show bactericidal effects [32]. Accordingly, L. inermis extract was shown to have bactericidal effects against $E$. coli ATCC 25922, P. aeruginosa ATCC27853, E. coli isolate, K. pneumonia isolate, S. aureus isolate and Streptococcus pyogenes isolate; but bacteriostatic activity against $S$. aureus ATCC 25923, MRSA ATCC ${ }^{\circ} 43300 \mathrm{TM}$, P. aeruginosa ATCC27853, K. pneumonia ATCC700603, $P$. aeruginosa isolate and S. algae isolate. Generally, the activity is considered to be high when MIC is less than 10 $\mu \mathrm{g} / \mathrm{mL}$, moderate when MIC is between 10 and100 $\mu \mathrm{g} /$ $\mathrm{mL}$ and low when MIC is greater than $100 \mu \mathrm{g} / \mathrm{m}$ [33].

$A$. indica and $A$. aspera extracts with MICs ranging from $25.0 \pm 0.0 \mathrm{mg} / \mathrm{mL}$ to $100.0 \pm 0.0 \mathrm{mg} / \mathrm{mL}$, and $50.0 \pm$ 0.0 to $200.0 \pm 0.0 \mathrm{mg} / \mathrm{mL}$, respectively, had moderate to low activity against the tested bacterial strains. Even though $A$. indica exhibited moderate to low activity against the tested strains, it showed bactericidal activity against all tested strains, with $\mathrm{MBC}$ values $\geq 200 \mathrm{mg} / \mathrm{mL}$ against all tested strains except $S$. aureus and Streptococcus pyogenes isolates.

The presence of bioactive phytochemical compounds such as alkaloids, flavonoids, tannins, phenols, steroids, and terpenoids in all three tested plant extracts accounted (either individually or in combination) for the broad-spectrum antimicrobial activities observed in this study, which is in agreement with the findings of previous studies $[34,35]$.

Possible modes of antibacterial action of some of the secondary metabolites could be described as follows: Tannins may act by inactivating microbial adhesins, 
enzymes and cell envelope transport proteins [34]; flavonoids by altering the cell membranes of microbes and inhibiting energy metabolism and synthesis of nucleic acids [36], alkaloids by disrupting the cell wall and /or inhibiting Deoxyribonucleic acid (DNA) synthesis (Ref?); anthraquinones by increasing the levels of superoxide anions and/or singlet oxygen molecules [37], and diterpenes and phenolic compounds by disrupting microbial cell membranes [38].

\section{Conclusion}

The methanol extracts of $L$. inermis, A. indica and $A$. aspera leaves exhibited antimicrobial activity against selected bacterial isolates involved in lymphoedemaassociated wound infections and standard ATCCs including methicillin resistant $S$. Aureus. L. inermis extract demonstrated high activity and had bactericidal effects against most of the tested bacterial strains. However, $A$. indica and $A$. aspera extracts showed low to moderate activity against most tested strains at $400 \mathrm{mg} / \mathrm{mL}$. These findings support the traditional claim that the three medicinal plants have antibacterial activity in wound infections. Further investigations, however, need to be carried out before recommending their use.

\begin{abstract}
Abbreviations
ANOVA: One-way analysis of variance; ATCC: American Type Culture Collection; $\mathrm{CC}_{50}$ : Minimum dose that is toxic to $50 \%$ of cells; CFU: Colony forming unit; Cl: Confidence interval; CLSI: The Clinical and Laboratory Standards Institute; DMSO: Di-methyl-sulfoxide; DNA: Ribonucleic acid; mg/ mL: milli gram per ml; MHA: Mueller Hinton agar; MHB: Muller Hinton broth; MIC: Minimum inhibitory concentration; $\mathrm{IC}_{50}$ : Half minimum inhibitory concertation; MD: Mean difference; MDR: Multiple drug resistance; PBS: Phosphate buffered saline; MRSA: Methicillin resistance Staphylococcus aureus; SD: Standard deviation; SPSS: Statistical package for social science; WHO: World Health Organization; ZI: Zone of inhibition
\end{abstract}

\section{Acknowledgments}

We would like to thank CDT-Africa, Addis Ababa University for the field support, Ethiopian Public Health Institute for allowing us to use their laboratory, and Konchi Catholic Church Clinic for supporting sample collection. Our special gratitude to Clare Callow, Grit Gansch and Manuela McDermid for supporting the procurement of laboratory supplies. Special thanks to Dr. Getachew Addis, Dr. Abrham Tesfaye, Dr. Yimitubezenash Wolde-Amanuel, Mr. Tesfa Addis, Mr. Zeleke Ayenew, Sister Cicily Joseph Cherriakara, Mr. Abdi Samuel, and Mr. Estifanos Tsige for the support during study design, sample collection and laboratory work.

\section{Authors' contributions}

$D N, G D, E M, B A L$ and $A F$ were involved in conceptualization and design of the study, and in analysis and interpretation of the data. DN wrote the first draft of the manuscript and DN, GD, EM, BAL and AF critically reviewed the manuscript for intellectual content. All authors have read and approved the final manuscript.

\section{Funding}

This research was funded by the National Institute for Health Research (NIHR) Global Health Research Unit on NTDs at BSMS using UK aid from the UK Government to support global health research. NIHR was not involved in the design of the study, collection, analysis, interpretation of data and in writing the manuscript. The views expressed in this publication are those of the author (s) and not necessarily those of the NIHR or the UK Department for Health and Social Care.

\section{Availability of data and materials}

The datasets during and/or analysed during the current study available from the corresponding author on reasonable request.

\section{Ethics approval}

Ethical approval was obtained from the Brighton and Sussex Medical School, Research Governance and Ethics Committee (ER/BSMS9DY2/1), and Institutional Review Board (004/19/CDT), Addis Ababa University, College of Health Sciences, Addis Ababa, Ethiopia. Written informed consent in the local language was obtained from the study participants before collection of the swab samples.

\section{Consent for publication}

Not applicable.

\section{Competing interests}

None declared.

\section{Author details}

${ }^{1}$ Centre for Innovative Drug Development and Therapeutic Trials for Africa (CDT-Africa), College of Health Sciences, Addis Ababa University, P.O. Box 9086, Addis Ababa, Ethiopia. ${ }^{2}$ Centre for Global Health Research, Brighton and Sussex Medical School, University of Sussex, Brighton BN1 9PX, UK. ${ }^{3}$ School of Public Health, Addis Ababa University, P.O. Box 9086, Addis Ababa, Ethiopia. ${ }^{4}$ Department of Pharmacology and Clinical Pharmacy, College of Health Sciences, Addis Ababa University, Addis Ababa, Ethiopia.

Received: 23 September 2020 Accepted: 9 December 2020

Published online: 03 January 2021

\section{References}

1. Jamal BS, Mohammed IA. Bacterial isolates from wound infections and their antibiotic susceptibility pattern in Kassala teaching hospital, Sudan. Am J Microbiol Res. 2019;7(4):102-7.

2. Keeley V, Riches K. Cellulitis treatment for people with lymphoedema : UK audit. J Lymphoedema. 2009;4(2):1-8.

3. Fife CE, Farrow W, Hebert AA, Armer NC, Stewart BR, Cormier JN, et al. Skin and wound care in lymphedema patients : A taxonomy, primer, and literature review. Adv Skin Wound Care. 2017;30:305-18.

4. Ayman A, Grada TJP. Lymphedema pathophysiology and clinical manifestations. Am Acad Dermatology, Inc. 2017;77(6):12.

5. Eagle M. Understanding cellulitis of the lower limb. Wound Essent. 2007;2:8,

6. Park SI, Yang EJ, Kim DK, Jeong HJ, Kim GC, Sim YJ. Prevalence and epidemiological factors involved in cellulitis in korean patients with lymphedema. Ann Rehabil Med. 2016;40(2):326-37.

7. Ali NAA, Ju W. Screening of Yemeni medicinal plants for antibacterial and cytotoxic activities. J Ethnopharmacol. 2001;8741:173-9.

8. Mummed B, Abraha A, Feyera T, Nigusse A, Assefa S. In Vitro antibacterial activity of selected medicinal plants in the traditional treatment of skin and wound infections in eastern Ethiopia. Biomed Res Int. 2018;2018:1862401.

9. Uthayarasa K, Pathmanathan K, Jeyadevan JP, Jeyaseelan EC. Antibacterial activity and qualitative phytochemical analysis of medicinal plant extracts obtained by sequential extraction method. Int J Integr Biol. 2010;10(2):76-81.

10. Pandey A, Tripathi S, Pandey CA. Concept of standardization, extraction and pre phytochemical screening strategies for herbal drug. J Pharmacogn Phytochem JPP. 2014;115(25):115-9.

11. Hudzicki J. Kirby-Bauer disk diffusion susceptibility test protocol. American Society for Microbiology; 2016: 3-23.

12. Kuete V, Betrandteponno R, Mbaveng AT, Tapondjou LA, Meyer JJM, Barboni $L$, et al. Antibacterial activities of the extracts, fractions and compounds from Dioscorea bulbifera. BMC Complement Altern Med. 2012; 12:228.

13. Clinical and Laboratory Standards Institute. Performance Standards for Antimicrobial Susceptibility Testing; Twenty-First Informational Supplement. CLSI document M100-S21, vol. 31. Wayne: Clinical and Laboratory Standards Institute; 2011.

14. Tadesse B, Yinebeb T, Ketema B. Antibacterial activity of selected medicinal plants used in South-Western Ethiopia. African J Microbiol Res. 2016;10(46): 1961-72.

15. Usman RA, Rabiu U. Antimicrobial activity of Lawsonia inermis ( henna ) extracts. Bayero J Pure Appl Sci. 2006;11(1):167-71. 
16. Khaliq FA, Raza M, Hassan SU, lqbal J, Aslam A, Aun M, et al. Formulation, characterization and evaluation of in vivo wound healing potential of Lawsone ointment. Am J Adv Drug Deliv. 2018;06(01):61-8.

17. Manivannan R, Aeganathan R, Prabakaran K. Anti-microbial and antiinflammatory flavonoid constituents from the leaves of Lawsonia inermis. J Phytopharm. 2015;4(4):212-6.

18. Kannahi M, Nadu T. Antimicrobial activity of Lawsonia inermis leaf extracts against some human pathogens. Int J Curr Microbiol App Sci. 2013;2(5):342-9.

19. Badoni R, Kumar D, Combrinck S, Cartwright-jones C, Viljoen A. Lawsonia inermis L. ( henna ): Ethnobotanical, phytochemical and pharmacological aspects. J Ethnopharmacol. 2014;155(1):1-24. Available from:. https://doi.org/ 10.1016/j.jep.2014.05.042.

20. Kamal M, Jawaid T. Pharmacological activities of Lawsonia inermis Linn. |A review. Int J Biomed Res. 2011;1(2).

21. Dahake PR, Naik P, Pusad M. Study on antimicrobial potential and preliminary phytochemical screening of Lawsonia inermis Linn. Int J Pharm Sci Res. 2015;6(8):3344-50.

22. Galeane MC, Martins CHG, Massuco J, Bauab TM, Sacramento LVS. Phytochemical screening of Azadirachta indica A . Juss for antimicrobial activity. African J Microbiol Res. 2017;11(4):117-22.

23. Rasool M, Malik A, Arooj M, Alam MZ, Alam Q, Asif M, et al. Evaluation of antimicrobial activity of ethanolic extracts of Azadirachta indica and Psidium guajava against clinically important bacteria at varying $\mathrm{pH}$ and temperature. Biomed Res- India. 2017;28(1):134-9.

24. Mohammed HA, Omer AFA. Antibacterial activity of Azadirachta indica ( Neem ) leaf extract against bacterial pathogens in Sudan. Am J Res Commun. 2015;3(5):246-51

25. Edwin S, Jarald EE, Deb L, Jain A, Kinger H, Dutt KR, et al. Wound healing and antioxidant activity of Achyranthes aspera. Pharm Biol. 2009;46(12):824-8.

26. Srivastav S, Singh P, Mishra G, Jha KK, Khosa RL. Achyranthes aspera- An important medicinal plant: A review. J Nat Prod Plant Resour. 2011;1(1):1-14.

27. Elumalai EK, Chandrasekaran N, Thirumalai T, Sivakumar C, Therasa SV, David E. Achyranthes Aspera leaf extracts inhibited fungal growth. Int J PharmTech Res. 2009:1 (4):1576-8.

28. Taye B, Giday M, Animut A, Seid J. Antibacterial activities of selected medicinal plants in traditional treatment of human wounds in Ethiopia. Asian Pac J Trop Biomed. 2011;1(5):370-5.

29. Leach LC. Structural elucidation of some antimicrobial constituents from the leaf latex of aloe. BMC Complement Altern Med. 2015;15(270):1-7. Available from:. https://doi.org/10.1186/s12906-015-0803-4.

30. Owuama Cl. Determination of minimum inhibitory concentration ( MIC ) and minimum bactericidal concentration ( $\mathrm{MBC}$ ) using a novel dilution tube method. African J Microbiol Res. 2017;11(23):977-80.

31. Kouadri F. In vitro antibacterial and antifungal activities of the saudi Lawsonia inermis extracts against some nosocomial infection pathogens. J Pure Appl Microbiol. 2018;12(2):281-6.

32. Venkateswarulu TC, Srirama K, Mikkili I, Nazneen Bobby M, Dulla JB, Alugunulla VN, et al. Estimation of minimum inhibitory concentration (MIC) and minimum bactericidal concentration (MBC) of antimicrobial peptides of Saccharomyces boulardii against selected pathogenic strains. Karbala Int J Mod Sci. 2019;5(4):266-9.

33. Bianco ÉM, Krug JL, Zimath PL, Kroger A, Paganelli CJ, Boeder AM, et al. Antimicrobial (including antimollicutes), antioxidant and anticholinesterase activities of Brazilian and Spanish marine organisms - evaluation of extracts and pure compounds. Brazilian J Pharmacogn. 2015;25(6):668-76.

34. Begashaw B, Mishra B, Tsegaw A, Shewamene Z. Methanol leaves extract Hibiscus micranthus Linn exhibited antibacterial and wound healing activities. BMC Complement Altern Med. 2017;17(1):1-12.

35. Wolde T, Bizuayehu B, Hailemariam T, Tiruha K. Phytochemical analysis and antimicrobial activity of Hagenia abyssinica. Indian J Pharm Pharmacol. 2016; 3(3):127.

36. Gupta PD, Birdi TJ. Development of botanicals to combat antibiotic resistance. J Ayurveda Integr Med. 2017;8(4):266-75.

37. Malmir M, Serrano R, Silva O. Anthraquinones as potential antimicrobial agents-A review. In: Mendez-Vilas A, editor. Antimicrobial research: Novel bioknowledge and educational programs. Formatex; 2017. p. 55-61. Available from: http://www.formatex.info/microbiology6/book/55-61.pdf.

38. Tamokou JDD, Mbaveng AT, Kuete V. Antimicrobial activities of African medicinal spices and vegetables; 2017. p. 207-37.

\section{Publisher's Note}

Springer Nature remains neutral with regard to jurisdictional claims in published maps and institutional affiliations.

\section{Ready to submit your research? Choose BMC and benefit from:}

- fast, convenient online submission

- thorough peer review by experienced researchers in your field

- rapid publication on acceptance

- support for research data, including large and complex data types

- gold Open Access which fosters wider collaboration and increased citations

- maximum visibility for your research: over $100 \mathrm{M}$ website views per year

At $\mathrm{BMC}$, research is always in progress.

Learn more biomedcentral.com/submissions 